\title{
ASSESSMENT OF THE CREDIBILITY OF PUBLIC WEBSITES ABOUT MEDICINAL HERBS
}

\author{
N. Kováts ${ }^{1 *}$, K. Hubai $^{1}$, E. Horváth ${ }^{1}$ and G. Paulovits ${ }^{2}$ \\ ${ }^{1}$ University of Pannonia, Institute of Environmental Sciences \\ H-8200 Veszprém, Egyetem u. 10, Hungary; ${ }^{*}$ E-mail: kovats@almos.uni-pannon.hu \\ ${ }^{2}$ Balaton Limnological Institute, Centre for Ecological Research, Hungarian Academy of Sciences, \\ H-8237 Tihany, Klebelsberg K. u. 3, Hungary
}

(Received 30 January, 2018; Accepted 5 March, 2018)

\begin{abstract}
In recent decades, there has been a growing interest in the use of herbs and herbal medicinal products, both in developing and developed countries. While electronic medium has become a more and more important tool for presenting information about health-related issues, several studies demonstrated that the internet often contains inaccurate and/or misleading information. In our study we assessed 30 Hungarian websites and 2 cellphone applications intended for public use and evaluated the quality and credibility of the information presented about medicinal plants recommended. It was found that websites showed very diverse safety: most websites gave mixed information, that is, some medicinal herbs and their potential hazard were properly described, while others were not. There were, however, websites, which completely missed to give information about any potential hazard. As credibility of public websites can be in most cases questioned, it is strongly recommended for potential users to consult more than one source of information.
\end{abstract}

Key words: hazardous plants, medicinal herbs, safe use, web-based information

\section{INTRODUCTION}

In recent decades, the popularity of herbs and herbal medicinal products has been growing both in developing and developed countries, including Hungary. In developed countries, many patients or consumers are seeking herbal therapy assuming that it will promote healthier living (Ekor 2014).

However, while there is a quite general belief that herbal medicines are safe because they are "natural" (White et al. 2014), traditional is not necessarily safe. There are numerous risk factors associated with the use of herbal medicinal products, including unexpected toxicity (Jordan et al. 2010).

Due to the continuous development of analytical technology, identification and detection of secondary metabolites have considerably improved (Masullo et al. 2015), revealing the presence of potentially toxic bioactive compounds such as hepatotoxic pyrrolizidine alkaloids (PAs) (Kristanc and Kreft 2016a). Wiesner and Knöss (2014) discuss that a complete chemical profile should be given, including not only the major ingredients but all bioactive compounds. 
Unexpected toxicity also occurs in case of misidentification (Kristanc and Kreft 2016b), adulteration (Techen et al. 2014) or contamination. Contamination can be observed in polluted habitats, where the plants accumulate heavy metals and/or polyaromatic hydrocarbons (PAHs), either from contaminated soil or from atmospheric deposition (reviewed by Tripathy et al. 2015). Pesticide residues have also been detected (Zhang et al. 2012). Herbs or herbal preparations can be contaminated with mycotoxins, which might cause adverse human health effects (Ashiq et al. 2014). In some cases, even parasites have been found in herbal preparations (Mazzanti et al. 2008). Phytochemical variability might also be an issue: chemical composition and thus mode of action of the plant can be influenced by environmental factors (reviewed by Dhami and Mishra 2015).

Clinical reports prove that interactions with other drugs, either pharmaceutical or herbal, can pose actual human health hazard (e.g. Izzo and Ernst 2001, Jordan et al. 2010).

For the public, diverse information sources are available on the collection, cultivation, identification, mode of action and preparation of herbs. They involve books, websites, lectures (also accessible on the internet), organised excursions and/or visits to botanical gardens. Electronic medium has become a more and more important tool for presenting information about health-related issues, including medicinal plant databases (Ningthoujam et al. 2012). For example, in the U.S., sixty-one percent of adults seek health information online (Kitchens et al. 2014).

Public websites, however, might lack quality assurance; in other words, the information provided by them might have been compiled without actual scientific review. Bearing in mind the growing interest towards herbal medicinal products and the potential hazards mentioned, the purpose of the study was to evaluate the credibility of readily available Hungarian websites about medicinal herbs. Another aspect of the evaluation was whether the database included protected species, indicating their legal status.

\section{METHODS}

Google-based search was done, using the selective key words: medicinal plants; everyday medicinal plants; common medicinal plants (in Hungarian: gyógynövények; mindennapi gyógynövények/gyógynövényeink; gyakori gyógynövények). Websites were evaluated in order of appearance. Exclusion criteria were:

- commercial ads (for example, advertising herbal products, books, training courses, etc.);

- simple compilation of publications;

- only a narrow collection of selected herbs, e.g. for losing weight. 
Websites were preferred which included a list of recommended medicinal herbs with:

- description (including taxonomy, habitat or other ecological traits);

- information on collection (methods, season, etc.);

- mode of action;

- suggested use, mode of preparation;

- additional information (e.g. photo, potential risks, etc.).

Websites were evaluated based on:

- number of potentially hazardous plants per website;

- number of potentially hazardous plants per website inadequately described;

- number of protected species per website;

- number of protected species per website inadequately described (the website did not mention the protected status of the plant and did not inform the users that collection of any part of the specimen was strictly forbidden by Hungarian national legislation).

Plants included in the list of the (Hungarian) National Institute of Pharmacy and Nutrition (OÉTI 2013) were considered potentially toxic/hazardous (Table 1). In case of any doubt, community herbal monographs or public state-

Table 1

List of hazardous plants, which (1) were included in at least one of the websites accessed and (2) are included in the OÉTI list

\begin{tabular}{ll}
\hline Name of the plant & Active ingredients responsible for potential hazard \\
\hline Acorus calamus & asarone \\
Adonis sp. & cardenolide glycoside, adonitoxin \\
Alkanna tinctoria & pyrrolizidine alkaloids, likopsamin \\
Angelica archangelica & furocoumarins \\
Arctostaphylos uva-ursi & quinone, arbutin, metlarbutin \\
Aristolochia sp. & aristolochid acid and derivatives \\
Artemisia absinthium & $\alpha$-thujone \\
Asarum europaeum & $\beta$-asarone \\
Berberis vulgaris & isoquinoline alkaloids, berberine \\
Bryonia sp. & cytotoxic cucurbitacin \\
Chelidonium majus & isoquinoline alkaloids, chelidonine, protopine \\
Cimicifuga racemosa & actein, 27-deoxi-actein, cimicifugoside \\
Colchicum sp. & alkaloids, colchicine \\
Conium maculatum & alkaloids: coniine, coniceine \\
\hline
\end{tabular}


Table 1 (continued)

\begin{tabular}{|c|c|}
\hline Name of the plant & Active ingredients responsible for potential hazard \\
\hline Convallaria majalis & cardenolide glycosides, convallatoxin, convallozid \\
\hline Datura sp. & tropane alkaloids: atropine, scopolamine \\
\hline Digitalis sp. & cardenolide glycosides, digitoxin, lanatoside \\
\hline Dryopteris filix-mas & phloroglucin derivatives \\
\hline Ephedra sp. & phenilalkilaminalkaloids, ephedrine, norephedrine \\
\hline Euonymus sp. & evonine type alkaloids, evonin; cardenolide, evonoside \\
\hline Euphorbia sp. & tiglinane, ingenane and daphnane type phorbol esters \\
\hline Fumaria officinalis & isoquinoline alkaloids, scoulerine, protopine \\
\hline Genista tinctoria & alkaloids: anagirin, cytisine, sparteine; izoflavone, genistein \\
\hline Gratiola officinalis & triterpene glykoside, graciozid; cucurbitacin \\
\hline Hedera helix & saponins, $\alpha($ alpha)-hederin \\
\hline Helleborus sp. & $\begin{array}{l}\text { alkaloids, celliamine, sprintilline; cardenolide glycoside, hel- } \\
\text { lebrin; toxic saponins, helleborin }\end{array}$ \\
\hline Hyoscyamus sp. & tropane alkaloids, hyoscyamine, scopolamine \\
\hline Hypericum perforatum & naphtodiantrones, hypericin, pseudohypericin \\
\hline Leonorus cardiaca & diterpenes of labdane skeleton lactones, leocardin; alkaloids \\
\hline Lycopodium clavatum & alkaloids, lycopodin \\
\hline Melilotus officinalis & coumarin \\
\hline Oenanthe sp. & oenantotoxin, apiol, myristicin \\
\hline Paeonia officinalis & - \\
\hline Petasites hybridus & (un/) insaturated pyrrolizidine alkaloids \\
\hline Pulsatilla sp. & protoanemonin, ranunculin \\
\hline Rhamnus frangula & hydroxyanthraquinone, frangulin, glucofrangulin \\
\hline Scopolia sp. & tropane alkaloids, atropine, scopolamine \\
\hline Senecio sp. & (un/) insaturated pyrrolizidine alkaloids, senecionine \\
\hline Solanum dulcamara & steroidal alkaloids and saponins \\
\hline Symphytum sp. & pyrrolizidine alkaloids \\
\hline Taxus baccata & diterpene pseudoalkaloids, taxine A and B \\
\hline Teucrium chamaedrys & neo-clerodane, teucrium lactones \\
\hline Tussilago farfara & pyrrolizidine alkaloids \\
\hline Veratrum album & steroidal alkaloids, protoveratrin A and B \\
\hline Viscum album & Viscum lectin I-III; viscotoxin \\
\hline
\end{tabular}


ments (reviewed by Chinou 2014) were consulted. In case of Fumaria officinalis for example, the OÉTI list states that: "not enough data are available to assess safety". The Community Monograph (HMPC 2011a) gives special warnings and precautions for use, such as contraindications in case of biliary diseases and hepatitis.

Description was considered safe if the website mentioned the potential toxicity of the herb, or gave another special warnings, such as potential contraindications, or safe dose (e.g. in case of Artemisia absinthium a daily intake of $3.0 \mathrm{mg} /$ person is acceptable for a maximum duration of use of 2 weeks, due to the thujone content (HMPC 2009)). Decree.

Legal status of the species was given according to the 13/2001 (V. 9.) KöM

\section{RESULTS}

Altogether 30 websites and 2 cellphone applications were assessed. Table 2 gives a summary about (1) number of potentially hazardous plants per website; (2) number of potentially hazardous plants per website with lacking/ misleading information about the potential hazards; (3) number of protected species per website and (4) number of protected species per website with lacking/misleading information about the legal status.

Considering potential risk of herbs, credibility and safety of websites varied to a high extent. The lowest category of safety and credibility is represented by websites where no information was given about potential hazards (e.g. W1, W10 and W11). Most websites gave mixed information: some medicinal herbs and their potential risks were properly described while others

Table 2

Number of potentially hazardous plants per website $(\mathrm{PH})$; number of potentially hazardous plants per website with missing/incorrect information on the potential hazard $\left(\mathrm{PH}^{-}\right)$; number of protected species per website (PS); number of protected species per website with missing/incorrect information on the legal status (PS-); number of all taxa included; short description of the website. W1-W30: Websites 1-30; App1-App2: cellphone applications 1-2

\begin{tabular}{ccccccl}
\hline $\begin{array}{c}\text { Web- } \\
\text { site }\end{array}$ & PH & PH $^{-}$ & PS & PS $^{-}$ & $\begin{array}{c}\text { No of all } \\
\text { taxa }\end{array}$ & Short description \\
\hline W1 & 7 & 7 & 2 & 0 & 31 & advices in everyday health issues \\
W2 & 10 & 0 & 5 & 3 & 102 & reliable relic of medical plants \\
W3 & 2 & 1 & 0 & 0 & 15 & gives alternative medicine option \\
\hline
\end{tabular}


Table 2 (continued)

\begin{tabular}{|c|c|c|c|c|c|c|}
\hline $\begin{array}{l}\text { Web- } \\
\text { site }\end{array}$ & $\mathrm{PH}$ & $\mathrm{PH}^{-}$ & PS & PS- $^{-}$ & $\begin{array}{l}\text { No of all } \\
\text { taxa }\end{array}$ & Short description \\
\hline W4 & 3 & 1 & 0 & 0 & 53 & $\begin{array}{l}\text { list of herbs recommended for different } \\
\text { illness }\end{array}$ \\
\hline W5 & 1 & 1 & 0 & 0 & 9 & helping in everyday health \\
\hline W6 & 23 & 3 & 10 & 2 & 183 & $\begin{array}{l}\text { herbs a-z, application, therapy, property, } \\
\text { cultivation }\end{array}$ \\
\hline W7 & 11 & 4 & 7 & 0 & 90 & collection of most important herbs \\
\hline W8 & 1 & 1 & 1 & 1 & 207 & collection of herbs, herbal teas and spices \\
\hline W9 & 14 & 3 & 7 & 5 & 49 & showing the healing power of nature \\
\hline W10 & 9 & 9 & 4 & 2 & 10 & description of herbal products \\
\hline W11 & 7 & 7 & 2 & 0 & 31 & $\begin{array}{l}\text { suggests that 'every complaint can be } \\
\text { cured by a herb' }\end{array}$ \\
\hline W12 & 25 & 13 & 16 & 15 & 246 & lexicon of herbal plants \\
\hline W13 & 3 & 2 & 0 & 0 & 32 & introduction to the world of herbs \\
\hline W14 & 4 & 0 & 1 & 0 & 55 & herbal teas and promotion \\
\hline W15 & 6 & 8 & 0 & 0 & 49 & general uses of herbs \\
\hline W16 & 11 & 5 & 3 & 3 & 109 & phytotherapy guide \\
\hline W17 & 23 & 0 & 1 & 0 & 119 & description of herbs \\
\hline W18 & 0 & 0 & 0 & 0 & 18 & description of herbs \\
\hline W19 & 5 & 2 & 4 & 3 & 170 & modern use of herbs \\
\hline W20 & 13 & 3 & 6 & 3 & 239 & description of herbs \\
\hline W21 & 1 & 1 & 0 & 0 & 53 & description of herbs \\
\hline W22 & 1 & 0 & 0 & 0 & 16 & the most common herbs around the house \\
\hline W23 & 17 & 10 & 7 & 0 & 73 & collection of herbs \\
\hline W24 & 7 & 4 & 3 & 1 & 72 & $\begin{array}{l}\text { schematic overview of herbs, herbs and } \\
\text { edible (wild) plants }\end{array}$ \\
\hline W25 & 4 & 0 & 0 & 0 & 23 & description of herbs \\
\hline W26 & 14 & 5 & 4 & 4 & 99 & effects of herbs \\
\hline W27 & 3 & 1 & 0 & 0 & 94 & description of herbs \\
\hline W28 & 38 & 25 & 18 & 17 & 240 & description of herbs \\
\hline W29 & 32 & 18 & 21 & 1 & 796 & general uses of herbs \\
\hline W30 & 24 & 5 & 13 & 2 & 700 & description of herbs \\
\hline App1 & 22 & 6 & 3 & 1 & 187 & description of herbs \\
\hline App2 & 6 & 0 & 2 & 0 & 183 & description of herbs \\
\hline
\end{tabular}


were not (e.g. W6 which included 23 potentially hazardous species, but only 3 were improperly described or W12, which included 25 potentially hazardous species, but gave inappropriate description for approximately half of them, 13). It is interesting to note that W28 and W29 covered the widest range of potentially hazardous plants ( 38 and 32 , respectively) and also, number of inappropriately described plants was the highest in their case, 25 and 18, respectively. Of cellphone applications, the wider database (App1) included 22 potentially hazardous species, but description of only 6 were found as inappropriate. The other included only 6 such species, but provided correct information on the potential hazard.

Considering the protected status of medicinal herbs, websites also varied to a great extent. For example, W12 included 16 protected species and 15 were improperly described; similarly, W28 included 18 protected species and for 17 of them, no information was provided about the legal status. On the contrary, W29 included 21 protected species and the conservation status of only 1 of them was missing.

\section{DISCUSSION}

As the number of people consulting the Internet in health-related issues is continuously rising, more and more studies attempt to assess the credibility of websites (e.g. Gao et al. 2015, Lederman et al. 2014).

Molassiotis and $\mathrm{Xu}$ (2004) evaluated safety issues of web-based information about herbal medicines in the treatment of cancer. In their study, a scoring system was applied to give a quantitative estimation about overall safety of the website. They concluded that based on these scores, "the safety of the web-based information on herbs in the treatment of cancer was low". While in our study commercial websites (advertising some herbal products) were excluded, the assessment of Molassiotis and Xu included such websites and found that they had the lowest safety scores.

In parallel with the growing interest in herbal medicinal products, there is an increasing concern about their safety on institutional level. The World Health Organisation (2004) recommends the safety monitoring of herbal medicines/traditional medicines. It might especially be useful in developing countries, where approximately $80 \%$ of the population relies on herbal remedies (Neergheen-Bhujun 2013). However, more and more studies prove that even such herbs, which have a long tradition can cause negative effects. For example, Haq (2004) in his review gives an extensive list of these herbs, which include ginkgo (Ginkgo biloba) and ginseng (Panax ginseng). Assessment of adverse effects is based on patients' reports and/or animal toxicological tests. 
Adverse effects of alternative medicine have already been reported in Europe. Jacobsson et al. (2009) covered an approximately 20-year period (between 1987 and 2006) and found 967 suspected adverse reactions related to different complementary and alternative medicine (CAM) products. Surprisingly, the most reported cases $(8.1 \%)$ were connected to purple coneflower (Echinacea purpurea), an herb, which is non-native in Hungary, but is widely used. Medicinal herbs might also be used as Plant Food Supplements (PFS). In the framework of the European Project PlantLIBRA, a survey was performed involving over 2300 adults from 6 countries (Finland, Germany, Italy, Romania, Spain and UK). Complaints regarding adverse reactions were also assessed. Causality was likely in 56 out of 87 cases (Restani et al. 2016).

It is not the main intention of this paper to discuss all potentially toxic/hazardous plants included in the websites assessed in details. However, some plants are taken as examples. Comfrey (Symphytum officinale L., family Boraginaceae) is known to contain pyrrolizidine alkaloids (PAs), which have hepatotoxic effect. Allgaier and Franz (2015) review the regulations concerning the human exposure to PAs in herbal medicine products: in most cases, daily exposure is limited and/or the maximum period for its application is given (it is interesting to note, however, that the EMA public statement (EMA 2014) does not discriminate between oral and dermal exposure). As the above mentioned list of the Hungarian National Institute of Pharmacy and Nutrition (OÉTI 2013) clearly prohibits its use, we assessed how reliable information is given by the websites presented in this study. Of the 30 websites, 18 included comfrey and 5 provided misleading information.

The use of another potentially hepatotoxic plant, greater celandine (Chelidonium majus L.) was causally related to liver injury according to European case reports (Teschke et al. 2012a) and hepatitis (Moro et al. 2009). All these authors emphasize that concern should be increased about the safety of oral use of $C$. majus. In our study, the plant was included in 12 websites, 7 of them gave proper warning. In general, reported cases of herbal hepatotoxicity are the most often discussed and reviewed (Ernst 2003, Stickel and Shouval 2015, Teschke et al. 2012b).

Another example is St. John's wort (Hypericum perforatum), which was included in most of the websites, 25 . Roughly $50 \%$ (13) gave proper safety instructions. The plant is most valued for treating depression and other mood disorders; exact modes of action are reviewed by Klemow et al. (2011). The main active compound is the photodynamic active plant pigment hypericin. Phototoxic symptoms ("hypericism") have been observed in grazing animals consuming large amounts of St. John's wort, however, standard dosage used in case of mood disorders does not produce phototoxic symptoms in humans (Schempp et al. 2002). 
In addition to its antidepressant capacity, St. John's wort is used for the topical treatment of superficial wounds such as scars and burns. Schempp et al. (2000) assessed the photosensitizing capacity of topical application of $\mathrm{Hy}$ pericum oil (hypericin $110 \mu \mathrm{g} / \mathrm{mL}$ ) and Hypericum ointment (hypericin $30 \mu \mathrm{g} /$ $\mathrm{mL}$ ) on volunteers. While no severe phototoxic potential was demonstrated, an increase of the erythema-index could be detected following the treatment with the Hypericum oil.

However, clinical trials prove that much higher risk is posed by the plant via the interaction with certain drugs, affecting their systemic bioavailability (Izzo and Ernst 2001, Mills et al. 2004). For example, reduced plasma concentration of antiretroviral and anticancer drugs was reported (Borrelli and Izzo 2009).

Recognising the potential risks associated with the use of herbal medicinal products (HMPs), Directive 2004/24/EC was issued in the European Union (Knöss and Chinou 2012). Naturally, its main field is the regulation of the market of such products. The public can be informed about the safe use or potential risk of herbs and herbal products by Community herbal monographs, Community list entries or public statements (PS) (reviewed by Chinou 2014). Community monographs are issued by the Committee on Herbal Medicinal Products, while Community list entries are published by the European Commission. Both Monographs and List entries provide a final and complete assessment of the safety and traditional use, but Community list entries are regarded as legally binding (Peschel 2014). Public statements have been published when the assessment could not be completed due to lack of data or safety issues emerged. For example, the PS on C. majus formulates the problems: gives chemical description of alkaloid content and also summarises reported adverse drug reactions. It also gives a conclusion, including the following statements: "the benefit-risk assessment of oral use of Chelidonium majus is considered negative with respect to the establishment of a community monograph" and "safer herbal medicinal products are available in the indication in question" (HMPC 2011b).

As a conclusion, it has been revealed by our study that the websites evaluated showed very diverse credibility, so in case of any doubt it is strongly recommended for potential users to consult more than one sources of information. Elvin-Lewis (2001) in an excellent work (Should we be concerned about herbal remedies) summarises all potential risks and formulates some useful guidelines. These include, among others, the following points: "be informed, seek out unbiased, scientific sources" and "know benefits and risks and potential side effects".

On the other hand, however, websites and cellphone applications are flexible in a way that their content can be continuously reviewed and im- 
proved. It should be very important in the case of cellphone applications, which will most possibly gain wider publicity in the near future.

Acknowledgements - The authors acknowledge the financial support of Széchenyi 2020 under the EFOP-3.6.1-16-2016-00015. We would like to express our thanks to Ms Dorina Diósi for technical help.

\section{REFERENCES}

Allgaier, C. and Franz, S. (2015): Risk assessment on the use of herbal medicinal products containing pyrrolizidine alkaloids. - Regulatory Toxicol. Pharmacol. 73: 494-500. https://doi.org/10.1016/j.yrtph.2015.09.024

Ashiq, S., Hussain, M. and Ahmad, B. (2014): Natural occurrence of mycotoxins in medicinal plants: a review. - Fungal Genetics and Biology 66: 1-10. https://doi.org/10.1016/j. fgb.2014.02.005

Borrelli, F. and Izzo, A. A. (2009): Herb-drug interactions with St John's wort (Hypericum perforatum): an update on clinical observations. - The AAPS Journal 11(4): 710-727. https://doi.org/10.1208/s12248-009-9146-8

Chinou, J. (2014): Monographs, list entries, public statements. - J. Ethnopharmacol. 158: 458462. https://doi.org/10.1016/j.jep.2014.08.033

Committee on Herbal Medicinal Products (HMPC) (2009): Community herbal monograph on Artemisia absinthium L., herba. - EMEA/HMPC/234463/2008

Committee on Herbal Medicinal Products (HMPC) (2011a): Community herbal monograph on Fumaria officinalis L., herba. - EMA/HMPC/574766/2010

Committee on Herbal Medicinal Products (HMPC) (2011b): Public statement on Chelidonium majus L., herba. - EMA/HMPC/743927/2010

Dhami, N. and Mishra, A. D. (2015): Phytochemical variation: how to resolve the quality controversies of herbal medicinal products? - J. Herbal Medicine 5: 118-127. https:// doi.org/10.1016/j.hermed.2015.04.002

Ekor, M. (2014): The growing use of herbal medicines: issues relating to adverse reactions and challenges in monitoring safety. - Frontiers in Pharmacol. 4: 177. https://doi. org/10.3389/fphar.2013.00177

Elvin-Lewis, M. (2001): Should we be concerned about herbal remedies. - J. Ethnopharmacol. 75: 141-164. https://doi.org/10.1016/S0378-8741(00)00394-9

Ernst, E. (2003): Serious adverse effects of unconventional therapies for children and adolescents: a systematic review of recent evidence. - Eur. J. Pediatrics 162: 72-80. https:// doi.org/10.1007/s00431-002-1113-7

European Medicines Agency (EMA) (2014): Public statement on the use of herbal medicinal products containing toxic, unsaturated pyrrolizidine alkaloids (PAs). - EMA/HMPC/ 893108/2011, Committee on Herbal Medicinal Products (HMPC) 24 November 2014, $24 \mathrm{pp}$.

Gao, Q., Tian, Y. and Tu, M. (2015): Exploring factors influencing Chinese user's perceived credibility of health and safety information on Weibo. - Computers in Human Behavior 45: 21-31. https://doi.org/10.1016/j.chb.2014.11.071 
Haq, I. (2004): Safety of medicinal plants. - Pakistan J. Medical Res. 43(4): 1-8.

Izzo, A. A. and Ernst, E. (2001): Interactions between herbal medicines and prescribed drugs: a systematic review. - Drugs 61(15): 2163-2175. https://doi.org/10.2165/00003495200161150-00002

Jacobsson, I., Jönsson, A. K., Gerdén, B. and Hägg, S. (2009): Spontaneously reported adverse reactions in association with complementary and alternative medicine substances in Sweden. - Pharmacoepidemiology and Drug Safety 18: 1039-1047. https://doi. org/10.1002/pds.1818

Jordan, S. A., Cunningham, D. G. and Marles, R. J. (2010): Assessment of herbal medicinal products: challenges, and opportunities to increase the knowledge base for safety assessment. - Toxicol. and Appl. Pharmacol. 243: 198-216. https://doi.org/10.1016/j. taap.2009.12.005

Kitchens, B., Harle, C. A. and Li, S. (2014): Quality of health-related online search results. Decision Support Systems 57: 454-462. https://doi.org/10.1016/j.dss.2012.10.050

Klemow, K. M., Bartlow, A., Crawford, J., Kocher, N., Shah, J. and Ritsick, M. (2011): Medical attributes of St. John's wort (Hypericum perforatum). - In: Benzie, I. F. F. and WachtelGalor, S. (eds): Herbal medicine: biomolecular and clinical aspects. 2nd edition. CRC Press, Boca Raton (FL), pp. 211-229.

Knöss, W. and Chinou, I. (2012): Regulation of medicinal plants for public health - European community monographs on herbal substances. - Planta Medica 78: 1311-1316. https://doi.org/10.1055/s-0031-1298578

Kristanc, L. and Kreft, S. (2016a): European medicinal and edible plants associated with subacute and chronic toxicity part II: Plants with hepato-, neuro-, nephro- and immunotoxic effects. - Food and Chem. Toxicol. 92: 38-49. https://doi.org/10.1016/j. fct.2016.03.014

Kristanc, L. and Kreft, S. (2016b): European medicinal and edible plants associated with subacute and chronic toxicity part I.: Plants with carcinogenic, teratogenic and endocrine-disrupting effects. - Food and Chem. Toxicol. 92: 150-164. https://doi. org/10.1016/j.fct.2016.04.007

Lederman, R., Fan, H., Smith, S. and Chang, S. (2014): Who can you trust? Credibility assessment in online health forums. - Health Policy and Technol. 3: 13-25. https://doi. org/10.1016/j.hlpt.2013.11.003

Masullo, M., Montoro, P., Mari, A., Pizza, C. and Piacente, S. (2015): Medicinal plants in the treatment of women's disorders: analytical strategies to assure quality, safety and efficacy. - J. Pharm. Biomed. Analysis 113: 189-211. https://doi.org/10.1016/j. jpba.2015.03.020

Mazzanti, G., Battinelli, L., Daniele, C., Costantini, S., Ciaralli, L. and Evandri, M. G. (2008): Purity control of some Chinese crude herbal drugs marketed in Italy. - Food and Chem. Toxicol. 46: 3043-3047. https://doi.org/10.1016/j.fct.2008.06.003

Mills, E., Montori, V. M., Wu, P., Gallicano, K., Clarke, M. and Guyatt, G. (2004): Interaction of St John's wort with conventional drugs: systematic review of clinical trials. - British Medical Journal 329(7456): 27-30. https://doi.org/10.1136/bmj.329.7456.27

Molassiotis, A. and Xu, M. (2004): Quality and safety issues of web-based information about herbal medicines in the treatment of cancer. - Complementary Therapies in Medicine 12: 217-227. https://doi.org/10.1016/j.ctim.2004.09.005

Moro, P. A., Cassetti, F., Giugliano, G., Falce, M. T., Mazzanti, G., Menniti-Ippolito, F., Raschettid, R. and Santuccioe, C. (2009): Hepatitis from Greater celandine (Cheli- 
donium majus L.): review of literature and report of a new case. - J. Ethnopharmacol. 124(2): 328-332. https://doi.org/10.1016/j.jep.2009.04.036

Neergheen-Bhujun, V. S. (2013): Underestimating the toxicological challenges associated with the use of herbal medicinal products in developing countries. - BioMed Res. Intern. 2013: 1-9. https://doi.org/10.1155/2013/804086

Ningthoujam, S. S., Talukdar, A. D., Potsangbam, K. S. and Choudhury, M. D. (2012): Challenges in developing medicinal plant databases for sharing ethnopharmacological knowledge. - J. Ethnopharmacol. 141: 9-32. https://doi.org/10.1016/j.jep.2012.02.042

OÉTI (2013): Plants not recommended in use in dietary supplements. (Étrend-kiegészitókben alkalmazásra nem javasolt növények, in Hungarian). - http://www.oeti.hu/download/negativlista.pdf (accessed 10.06.16).

Peschel, W. (2014): The use of community herbal monographs to facilitate registrations and authorisations of herbal medicinal products in the European Union 2004-2012. - J. Ethnopharmacol. 158: 471-486. https://doi.org/10.1016/j.jep.2014.07.015

Restani, P., Di Lorenzo, C., Garcia-Alvarez, A., Badea, M., Ceschi, A., Egan, B., Dima, L., Lüde, S., Maggi, F. M., Marculescu, A., Milà-Villarroel, R., Raats, M. R., Ribas-Barba, L., Uusitalo, L. and Serra-Majem, L. (2016): Adverse effects of plant food supplements self-reported by consumers in the PlantLIBRA survey involving six European countries. - PLoS One 11(2): e0150089. https://doi.org/10.1371/journal.pone.0150089

Schempp, C. M., Lüdtke, R., Winghofer, B. and Simon, J. C. (2000): Effect of topical application of Hypericum perforatum extract (St. John's wort) on skin sensitivity to solar simulated radiation. - Photodermatol., Photoimmunol. Photomed. 16: 125-128. https:// doi.org/10.1111/j.1600-0781.2000.160305.x

Schempp, C. M., Müller, K. A., Winghofer, B., Schöpf, E. and Simon, J. C. (2002): Johanniskraut (Hypericum perforatum L.) eine Pflanze mit Relevanz für die Dermatologie. - Der Hautarzt 53(5): 316-321. https://doi.org/10.1007/s00105-001-0317-5

Stickel, F. and Shouval, D. (2015): Hepatotoxicity of herbal and dietary supplements: an update. - Arch. Toxicol. 89: 851-865. https://doi.org/10.1007/s00204-015-1471-3

Techen, N., Parveen, I., Pan, Z. and Khan, I. A. (2014): DNA barcoding of medicinal plant material for identification. - Curr. Opinion Biotechnol. 25: 103-110. https://doi. org/10.1016/j.copbio.2013.09.010

Teschke, R., Xaver, G., Johannes, S. and Axel, E. (2012a): Suspected greater celandine hepatotoxicity: liver-specific causality evaluation of published case reports from Europe. - Eur. J. Gastroenterol. Hepatol. 24(3): 270-280. https://doi.org/10.1097/ MEG.0b013e32834f993f

Teschke, R., Wolff, A., Frenzel, C., Schulze, J. and Eickhoff, A. (2012b): Herbal hepatotoxicity: a tabular compilation of reported cases. - Liver Intern. 32(10): 1543-1556. https:// doi.org/10.1111/j.1478-3231.2012.02864.x

Tripathy, V., Basak, B. B., Varghese, T. S. and Saha, A. (2015): Residues and contaminants in medicinal herbs: a review. - Phytochem. Letters 14: 67-78. https://doi.org/10.1016/j. phytol.2015.09.003

White, A., Boon, H., Alraek, T., Lewith, G., Liu, J. P., Norheim, A. J., Steinsbekk, A., Yamashita, H. and Fønnebø, V. (2014): Reducing the risk of complementary and alternative medicine (CAM): challenges and priorities. - Eur. J. Integrative Medicine 6: 404-408. https://doi.org/10.1016/j.eujim.2013.09.006

Wiesner, J. and Knöss, W. (2014): Future visions for traditional and herbal medicinal products: a global practice for evaluation and regulation? - J. Ethnopharmacol. 158: 516518. https://doi.org/10.1016/j.jep.2014.08.015 
World Health Organization (WHO) (2004): WHO guidelines on safety monitoring of herbal medicines in pharmacovigilance systems. - Geneva, $82 \mathrm{pp}$.

Zhang, J., Wider, B., Shang, H., Li, X. and Ernst, E. (2012): Quality of herbal medicines: challenges and solutions. - Complementary Therapies in Medicine 20: 100-106. https://doi. org/10.1016/j.ctim.2011.09.004

\section{Supplementum: accessed websites}

http://ezoterika22.hu/?modul=oldal\&tartalom=1202511

http://fitoterapiakalauz.hu/gyogynovenyek-a-z/

http://gazkor.hu/gy4.html

http://gyogynovenyek.com/

http://gyogynovenyek.egeszseged.info/a-leggyakoribb-gyogynovenyek-a-haz-korul/

http://gyogynovenyek.info/category/gyogynoveny-lexikon/

http://gyorgytea.hu/gyogynovenyek-betegsegekre

http://gyógytea.com/gyogynoveny_lexikon

http://herbad.hu/gyogynovenyek-abc-sorrendben-v/

http://kinai-medicina.tienshoni.hu/kinai-medicina/gyogynovenyek.html

http://mammy.uw.hu/txt/fito/gynleir.htm

http://margit2.uw.hu/kertesz/fuszergyn.htm\#fusz

http://mecsektea.hu/tearol/gyogynovenyek-hatasai

http://napiegeszseg.blogspot.hu/p/gyogynovenyek-maria-treben.html\#.V1aVd08oeW9

http://novenyigyogyszer.hu/gyogynovenyek

http://orseggyogynoveny.uw.hu/gyogynovenyek-vadonelo.html

http://timcsigyogynoveny.blogspot.hu/2011/09/aggofu.html

http://vilagbiztonsag.hu/keptar/thumbnails.php?album=45

http://www.egeszsegtukor.hu/gyogynoveny-lexikon?letter=A

http://www.gyogynoveny.net/category/vadon-termo-gyogynovenyek/

http://www.gyogynovenyek.gportal.hu/gindex.php?pg=298121

http://www.gyogynovenyhatarozo.hu/temak/gyogynovenyek/

http://www.gyogynovenysziget.hu/gyogynovenyek/

http://www.gyogynoveny-volgy.hu/

https://www.hazipatika.com/gyogynovenytar/

http://www.mariatrebenpatikaja.hu/gyogynovenyek/?page=4

http://www.orvosok.hu/gyogynovenyek

http://www.patikamagazin.hu/gyogynovenyek/adatlap/191

http://www.shp.hu/hpc/web.php?azonosito=naturagyogynoveny\&oldalkod=1159036345

http://www.tarrdaniel.com/documents/Medicina/gyogynovenyek.html 